\title{
The Ability of Student Math Literation on Problem Based Learning Model (Pbl)
}

\author{
Heka M. Tabun ${ }^{1}$, Prida N. L. Taneo ${ }^{2 *}$, Farida Daniel ${ }^{3}$ \\ 1,2,3 Program studi pendidikan matematika, STKIP Soe, NTT, 85511, Indonesia \\ "Corresponding author: nemserayah.19@gmail.com, Soe, NTT, 85511, Indonesia.
}

\section{a r t i c l ein fo}

How to cite this article:

Tabun, H. M.., Taneo, P. N. L.., \& Daniel, F. (2019). Kemampuan Literasi Matematis Siswa pada Pembelajaran Model PBL. Eduma :

Mathematics Education Learning And Teaching, 9(1), 43 - 48

doi:http://dx.doi.org/10.24235/eduma.v9i1.6036

Article history:

Received: 02 06, 2020

Accepted: 03 02, 2020

Published: 07, 2020
Copyright (C) 2020

EduMa: Mathematics Education Learning and Teaching under the Creative Commons Attribution 4.0 International License.

\begin{abstract}
a b s t r a c t
THE ABILITY OF STUDENT' MATH LITERATION ON PROBLEM-BASED LEARNING MODEL (PBL) Students' ability to mathematical literacy is very important in their math learning process. Less ability of mathematical literacy as students' way of thinking, argumentation and creating is no improvement so they face difficulties in solving math problems in their learning process related to real life. The analysis of the result from students of SMP Kristen 1 Mollo Selatan shows that they are still a low inability of mathematical literacy. The effect are questions that used as the exercise are common questions and not related to real life. To solve this problem, the researcher implemented Problem Based Learning (PBL) as a teaching literacy to improve students' mathematical literacy abilities. This study will compare two classes in which one of them treated with PBL one of the other ones was not treated with PBL. A quasi-experiment quantitative method that used in this study with nonequivalent control group design. Two classes were selected as the sample by using simple random sampling. An essay test related to students' mathematical literacy ability was used as the instrument to collect the data. The analysis technique in this study was an independent sample t-test to the result showed that the class which was treated used the PBL method was better than the class which was not treated used the PBL method. Students' mathematical literacy ability in the PBL class was significantly proved in the high category with the score gain 0,8 .
\end{abstract}

Ke y word s :

Mathematical literacy ability, problem based learning, learning model 


\section{INTRODUCTION}

Mathematics equips students to have the ability to think logically, analytically, systematically, critically as well as the ability to cooperate, so it needs to be given to all students for every level of education from elementary to tertiary level (MONE, 2006). Mathematical learning objectives formulated by the National Council of Teaching Mathematics / NCTM (2000: 7) are students must have the ability: (1) mathematical communication, mathematical reasoning, (3) problem solving, (4) mathematical connections, and ( 5) mathematical representation. The purpose of learning mathematics is in accordance with aspects of developing mathematical literacy. Mathematical literacy is a person's ability to formulate, apply and interpret mathematics in various contexts, including the ability to do mathematical reasoning, using mathematical concepts, procedures, facts and tools to describe a phenomenon or event (OECD, 2016).

This mathematical literacy ability is in accordance with the mathematical abilities assessed in the Program for International Student Assessment (PISA). The mathematical abilities used in the PISA assessment (OECD, 2016), namely: (1) communication, (2) mathematizing, (3) representation, (4) reasoning and argument (reasoning and argument), (5) formulating strategies to solve problems (strategic devising for problem solving), (6) using symbolic, formal and technical language, and operations (using symbolic, formal and technical language and operations), (7) using mathematical tools (using mathematical tools). The mathematical literacy ability of students is very important in the process of learning mathematics. The lack of mathematical literacy ability makes the ability of students in reasoning, argumentation and creativity not develop so it is difficult to solve mathematical problems in everyday life.

A survey conducted by PISA to measure the ability of 15-year-old children in literacy reading, mathematics and science in 2015, ranked Indonesia 63 of the 70 surveyed countries. The score obtained by Indonesian students, especially mathematical literacy ability is 386 . This score is far below the established average of 490 (OECD, 2016). The results of this achievement indicate the mathematical literacy ability of Indonesian students is still relatively low. Students' mathematical literacy in PISA is divided into 6 levels. Mathematical literacy level 1 and level 2 is a group of questions with a low scale, level 3 and level 4 is a group of questions with a medium scale, while level 5 and level 6 is a group of questions with a high scale (Jufri, 2015). The assessment of mathematical literacy ability in the PISA study is assessed based on the low level up to the highest level.

The PISA study shows that Indonesian students are only able to solve level 1 and level 2 problems, which are levels that still refer to routine questions. Low PISA results are caused by many factors. One contributing factor is that students are generally only accustomed to working on 3 routine questions so that they are not trained in solving problems that are characterized by PISA (Linuhung, 2014). This is reinforced by the work of students of South Mollo 1 Christian Middle School 
in solving questions that are characterized by PISA. The work of students is presented in Figure 1.

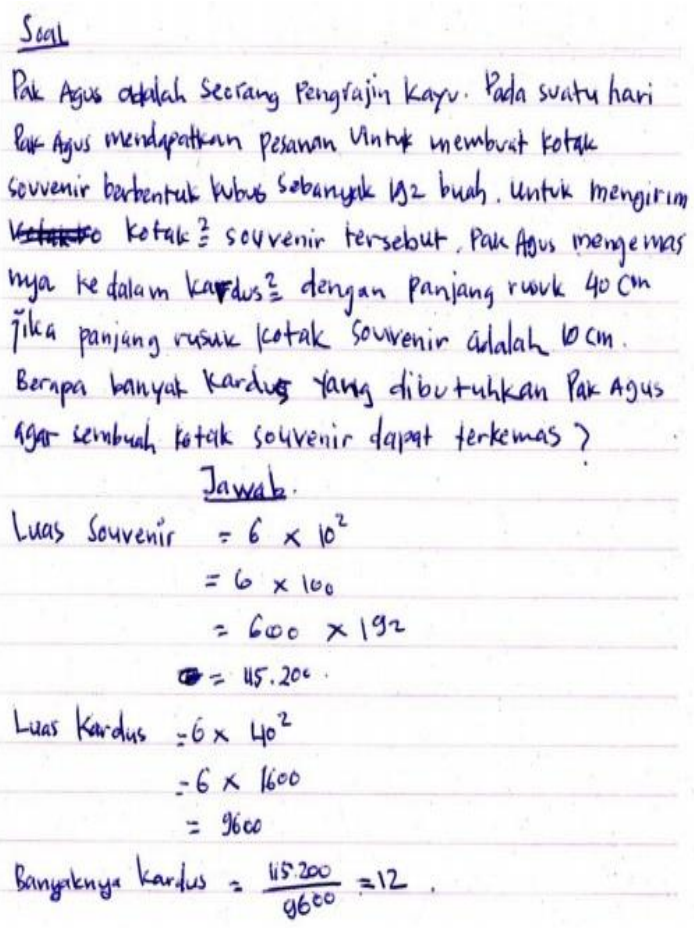

Figure 1. Student Work Results

Figure 1 shows that students misinterpret problems related to real life so that the strategies and concepts applied are not right. Student mistakes seen from the strategy used is to apply the broad concept of a cube while the actual is to apply the concept of volume. The results of the analysis of student work show that students are still having trouble solving non-routine problems.

Observation of the learning process in class VII Christian Middle School 1 South Mollo shows that the questions given to students as exercises or math assignments are routine problems and are less associated with real life. Problems like this do not develop the mathematical aspects of student literacy. In addition learning activities in the classroom are dominated by teachers and do not involve students, so it is necessary to design learning that involves many students. The design can be done by applying appropriate learning models, approaches and methods so as to involve students in learning. The solution that can overcome these problems is to apply one of the learning models that in the learning process applies real problems so that learning does not seem abstract or difficult and does not accustom students to work on routine problems. One alternative to overcome this problem is to apply the Problem Based Learning (PBL) model.

PBL model is a learning model that applies contextual problems so that it stimulates students to learn to solve realworld problems (Kemendikbud, 2013). Application of the PBL model will introduce students to problems or cases that are relevant to teaching materials and require students to do all kinds of activities to solve a problem.

The purpose of this study was to produce a study of the mathematical literacy ability of students in the classroom with PBL learning models and classes with learning without PBL models. This research was conducted at 1 Mollo Selatan 1 Christian Middle School, class VIII for the academic year 2017/2018 pythagorean theorem material with level 3 mathematical literacy questions.

\section{LITERATURE REVIEW}

The PBL learning model has six steps which are presented in Table 1.

Table 1

PBL Model Steps.

\begin{tabular}{ll}
\hline \multicolumn{1}{c}{ Fase } & \multicolumn{1}{c}{ Teacher's Role } \\
\hline $\begin{array}{l}\text { Student } \\
\text { orientation to } \\
\text { the problem }\end{array}$ & The teacher explains the \\
& $\begin{array}{l}\text { learning objectives, } \\
\text { explains everything that } \\
\text { will be needed, motivates } \\
\text { students to be seen in the } \\
\text { problem solving activities } \\
\text { they choose }\end{array}$
\end{tabular}


Organizing students for learning

Guide individual and group investigations

Develop and present the work

Analyze and evaluate the problem solving process
The teacher helps students define and organize learning assignments related to problems

The teacher encourages students to gather appropriate information, carry out experiments or observations to get explanations and problem solving

The teacher helps students plan and prepare appropriate work, carry out experiments or observations to get explanations and problem solving

The teacher helps students to reflect or evaluate their investigation and the processes they use

(Hamdayama, 2014: 212)

\section{RESEARCH METHODS}

The research method used is a quantitative method with a quasi experimental design type nonequivalent control group design. This study involved two classes, namely the experimental class and the control class. The experimental class was given the application of the PBL model, while the control class was without the PBL model. The population of this study was all students of class VIII as many as three classes and the sample consisted of two classes, namely class VIII $A$ as an experimental class and class VIII B as a control class determined using simple random sampling technique. The instrument in this study was a test of students 'mathematical literacy abilities in the form of problem descriptions compiled based on indicators of students' mathematical literacy abilities. The data analysis technique used is the normality test and homogeneity test as a prerequisite test, then proceed with the independent sample $t$ test and the gain score.

\section{RESULTS AND DISCUSSION}

The results of students' mathematical literacy abilities are presented in Table 2 .

Table 2

Results of Students' Mathematical Literacy Ability Tests

\begin{tabular}{ccccc}
\hline \multirow{2}{*}{ Statistics } & $\begin{array}{c}\text { Experimentation Class } \\
(\mathrm{N}=30)\end{array}$ & \multicolumn{2}{c}{$\begin{array}{c}\text { Control Class } \\
(\mathrm{N}=30)\end{array}$} \\
& Pre-test & Post-test & Pre-test & Post-test \\
\hline Maximum Score & 59,57 & 100 & 63,83 & 74 \\
Minimum Score & 10,64 & 66 & 10,64 & 32 \\
Average & 43,48 & 86,87 & 47,52 & 52,73 \\
Standard Deviasi & 16,22 & 8,75 & 12,13 & 11,44 \\
\hline
\end{tabular}

Table 2 shows that the experimental class and the control class experienced an increase in mathematical literacy ability with the results of pre-test scores lower than the post-test scores. This improvement was also seen from the average of the two classes with a pre-test mean value lower than the post-test average value. The standard deviation of the experimental class post-test data is smaller than the standard deviation of the control class which means that the ability of each student in the experimental class tends to be more homogeneous compared to the control class.

Continued analysis with independent $t$-sample tests showed that the results of this analysis showed that the average mathematical literacy ability of students in the experimental class was better than the control class. Analysis of the normalized gain score also shows that there is an increase in 6 mathematical 
literacy abilities of students in the experimental class with high categories. This increase was seen from the acquisition of the normalization gain score of the experimental class by 0.8 while the control class by 0.1 . This is consistent with the results of research conducted by Istiandaru, et al (2015) which states that the application of PBL models with scientific realistic approach and PISA assessment is better than conventional learning. The same thing was stated by Fitriono, et al (2015) who stated that the application of the PBL model with the PISA-rated PMRI approach could improve students' mathematical literacy abilities.

The mathematical literacy ability of students in the experimental class is better than the control class because PBL model learning presents contextual problems that stimulate students to learn to solve problems in real life. The research of Istiandaru, et al (2015) revealed that students' mathematical literacy ability can be increased if the material taught is directly related to daily life so that it can foster student interest in learning. Gagne in his theory also states that learning mathematics needs to be linked to real life so that it trains students to be able to investigate and solve problems, learn independently, be positive towards mathematics and know how to learn (Suherman et al, 2003: 33-34).

PBL model learning begins by presenting mathematical problems that exist in the real world so as to make learning more meaningful. The research of Istiandaru et al (2015) states that the PBL model makes the material being studied more meaningful because each material begins by presenting mathematical problems that are directly related to real life. Fitriono, et al (2015) also revealed that learning would be more meaningful if the material being taught began by giving mathematical problems taken directly from everyday life.

PBL model learning provides opportunities for students to discuss. Learning like this trains students to freely express their knowledge with their peers. Fitriono, et al (2015) in their research stated that PBL model steps provide opportunities for students to discuss with their peers so that it allows students to easily understand the material being studied. The mathematical literacy ability of the experimental class students is better than that of the control class also because students are accustomed to working on non-routine questions namely level 3 PISA questions. Research conducted by Fitriono, et al (2015) also states that students are able to solve literacy questions mathematically, if in the learning process, students are accustomed to working on mathematical literacy problems ranging from low levels to the highest level.

\section{CONCLUSIONS AND SUGGESTIONS}

Based on the description above it can be concluded that the mathematical literacy ability of level 3 students in PBL model learning is better than student 7 in learning without PBL model. Improving students' mathematical literacy skills in the classroom with PBL model learning is in the high category with a gain score of 0.8 .

It is recommended that mathematics subject teachers use the PBL model as an alternative in classroom learning. Other researchers interested in carrying out the same research are expected to increase their level of mathematical literacy ability to level 6.

\section{REFERENCES}

Depdiknas. (2006). Peraturan Pendidikan Nasional No 22,23,dan 24 Tahun 2006. Tentang Standar isi Untuk Satuan Pendidikan Dasar dan Menengah. Jakarta : Depdiknas.

Fitriono, Y., Rochmad, R., \& Wardono, W. (2016, February). Model PBL dengan Pendekatan PMRI Berpenilaian Serupa PISA untuk Meningkatkan Kemampuan Literasi Matematika Siswa. In PRISMA, Prosiding 
Seminar Nasional Matematika (pp. 514-526). Retrieved from https://journal.unnes.ac.id/sju/index.p hp/prisma/article/view/21683

Hamdayama. (2014). Model dan Metode Pembelajaran Kreatif dan Berkarakter. Bogor: Ghalia Indonesia.

Istiandaru, A. (2014). PBL Pendekatan Realistik Saintifik dan Asesmen PISA untuk Meningkatkan Kemampuan Literasi Matematika. Unnes Journal of Mathematics Education Research, 3(2).1-8. Retrieved from https://journal.unnes.ac.id/sju/index.php/uj $\underline{\text { mer/article/view/4620 }}$

Jufri, L. H. (2015). Penerapan Double Loop Problem Solving untuk Meningkatkan Kemampuan Literasi Matematis Level 3 pada Siswa Kelas VIII SMPN 27 Bandung. Lemma, 2(1), 52-62. https://doi.org/10.22202/jl.2015.v2i1.5 $\underline{26}$

Kemendikbud. (2013). Materi Pelatihan Guru Matematika SMP/MTs tentang Implementasi Kurikulum 2013.

Linuhung, N. (2014). Pengaruh Strategi Pemecahan Masalah WankatOreovocz dan Pembelajaran Teknik Probing terhadap Kemampuan Literasi Matematis Siswa SMP. AKSIOMA: Jurnal Program Studi
Pendidikan Matematika, 3(2).35-42. https://doi.org/10.24127/ajpm.v3i2.32

Graham, K. J., \& Fennell, F. (2001). Principles and standards for school mathematics and teacher education: Preparing and empowering teachers. School Science and Mathematics, 101(6), 319-327. https://doi.org/10.1111/j.19498594.2001.tb17963.x

OECD. (2016). PISA 2015 Assessment and Analytical Framework: Science, reading, mathematic and financial literacy. https://doi.org/10.1787/978926425542 $\underline{5-e n}$

Suherman, E. (2003). Strategi pembelajaran matematika kontemporer. Bandung: Jica. 